\title{
ASSESSING CITY GREENNESS USING TREE CANOPY COVER: THE CASE OF YOGYAKARTA, INDONESIA
}

\section{Rendy Bayu Aditya ${ }^{1 *}$, Muhammad Ulul Lizamun Ningam ${ }^{1}$}

'Urban and Regional Planning Program, Architecture and Planning, Faculty of Engineering, Universitas Gadjah Mada, Sleman, Indonesia

*Corresponding author: adityarb@ugm.ac.id

Received: November 1 ${ }^{\text {th }}, 2020$ / Accepted: February 16 th $^{\text {th }}, 2021$ / Published: April $1^{\text {st }}, 2021$

https://DOl-10.24057/2071-9388-2020-196

\begin{abstract}
The study aims to measure the greenness of an Indonesia city using tree canopy cover data. Rapid physical development brings impacts to the loss of urban trees, which leads to the increase of flooding risk, local temperature and pollution level. To address the issues, a baseline assessment of urban tree canopy existence is necessary as inputs for effective urban environmental management policies. The methods used in this research include 1) remote sensing and spatial analysis, and 2) simple quantitative analysis. Furthermore, three indicators are used in assessing the greenness, including 1) size of the canopy, 2) canopy cover percentage, and 3) canopy per capita. The results found that the city of Yogyakarta has a low level of greenness based on the canopy size in which covers only 467.37 ha or $14.38 \%$ of the total area. The second finding is Yogyakarta has an unequal distribution of canopy cover percentage in each district (kecamatan). The third finding is Yogyakarta City has a canopy per capita rate of $10.93 \mathrm{sq} \mathrm{m} /$ person. This number is below the UN recommendation of $15 \mathrm{sq}$ $\mathrm{m} /$ person. It indicates that residents have poor access to urban greenery. Additionally, the article discusses that the three indicators used have strength and weakness in measuring the level of greenness. Therefore, the assessment objectives must be taken into account. We recommend the use of each indicator as follows: 1) the canopy size is used as an initial inventory of the existence and distribution of the canopy, 2) the canopy cover percentage canopy percentage for measuring and comparing the level of greenness spatially and visually between areas, 3) the canopy per capita is used to measure the possibility of access and interaction of residents with the presence of a tree canopy. Cities' authority can use the information to measure the achievement of SDGs number 11, 13, or 15.
\end{abstract}

KEY WORDS: canopy cover; canopy per capita; city greenness; tree canopy; urban trees

CITATION: Rendy Bayu Aditya, Muhammad Ulul Lizamun Ningam (2021). Assessing City Greenness using Tree Canopy Cover: The Case of Yogyakarta, Indonesia. Geography, Environment, Sustainability, Vol.14, No 1, p. 71-80

https://DOI-10.24057/2071-9388-2020-196

ACKNOWLEDGEMENTS: The research received no funding

Conflict of interests: The authors reported no potential conflict of interest.

\section{INTRODUCTION}

The trees that live in urban areas, which are often called urban trees, provide essential benefits for the sustainability of the built environment. In urban areas with predominated impervious surfaces such as buildings and full of vehicle smoke pollution, some problems may appear including flooding, poor air quality, and hot local climate. Urban trees can provide ecosystem services to regulate those impacts and balance the environment, such as by absorbing stormwater run-off to reduce the risk of flooding (Y. Chen \& Borelli 2016; Farrugia, Hudson, \& McCulloch 2013; Pappalardo, La Rosa, Campisano, \& La Greca 2017), reducing air pollution (Ferranti, MacKenzie, Ashworth, \& Hewitt 2019; Martin, Chappelka, Loewenstein, \& Keever 2012) and moderating local climate (Ali \& Patnaik 2019; X. Chen et al. 2019; Norton et al. 2015; Zhou, Wang, \& Cadenasso 2017). Besides, the existence of urban trees can also mitigate climate change in cities because of trees' ability to absorb carbon emissions (McGovern \& Pasher 2016; Russo et al. 2014; Tang, Chen, \& Zhao 2016). The existence of trees also provides space for biodiversity to live in (Aronson et al. 2017; Fineschi \& Loreto 2020; Parmehr, Amati, Taylor, \&
Livesley 2016; Trees \& Design Action Group 2014). In the context of human and natural interactions, the presence of urban trees also positively influence residents' well-being and health (Fineschi \& Loreto 2020; Soga \& Gaston 2020; Ulmer et al. 2016). Accordingly, Sustainable Development Goals (SDGs) see urban trees as a significant aspect to achieve at least 3 goals which are Goal 11: Resilient and Sustainable cities, Goal 13: Climate Action, and Goal 15: Life on Land (Turner-Skoff \& Cavender 2019; United Nations 2019).

Rapid physical development happening in cities often results in the loss of trees (Brunner \& Cozens 2013; Guo, Morgenroth \& Conway 2018; Guo, Morgenroth, Conway \& Xu 2019; Nowak \& Greenfield 2018). The continued impact of the urban trees and its canopy loss will lead to reduced ecosystem services provided by trees for cities (Elmes et al. 2017; Riley \& Gardiner 2020). It means that environmental impacts are likely to happen more frequently in cities due to urban trees loss, such as urban heat island, flooding, and higher pollution. Awareness and concern for urban trees encourage urban environmental policies to maintain the existence of trees and tree canopies and try to raise their quantities and qualities (City of Melbourne 2012; Lavy \& 
Hagelman 2017, 2019; Martin et al. 2012; Papastavrou 2019; Phelan, Hurley, \& Bush 2019). Thus, to formulate better policies regarding urban trees management, cities need baseline information on urban tree canopy to (Intasen, Hauer, Werner, \& Larsen 2017; McGee, Day, Wynne, \& White 2012; Parmehr et al. 2016).

The purpose of this research is to measure the greenness of an Indonesia city using tree canopy cover data. Tree canopy is often used as a proxy to measure the level of greenness of an area (Ellis \& Mathews 2019; Nowak \& Greenfield 2018; Riley \& Gardiner 2020). The article contributes to the literature of urban tree canopy management and planning by utilising three indicators: 1) canopy size for assessing the existence of tree canopy, 2) the canopy cover percentage for assessing distribution and equality of tree canopy, and 3) the number of canopy per capita as a proxy for assessing the accessibility of residents to interact with nature.

\section{MATERIALS AND METHODS}

Yogyakarta was chosen to be the case study in this research because it is one of the Indonesian cities with a fast growth rate. Yogyakarta is the capital of the Yogyakarta Special Region. The physical size of Yogyakarta is 3,249.31 Ha. The total population of Yogyakarta City in 2018 was 427,498 with a density of 131.57 persons / Ha. The population growth in Yogyakarta City is at an average of $1.14 \%$ per year based on 2016-2019 data. Yogyakarta has 14 districts with various sizes. The development of Yogyakarta City is considered rapid and has caused several environmental impacts. A study explained that the level of air pollution in Yogyakarta City is increasing due to development activities (Saptutyningsih \& Ma'ruf 2015). Another research revealed that an urban heat island has occurred in several areas in the city of Yogyakarta as a result of the intensification of built elements along with the decline of natural elements in thea city (Husna, Fawzi \& Nur 2018). Thus, our research argues that a solution to overcome the issues is to maintain and increase the existence of urban trees, because they provide ecosystem services such as pollution removal (Ferranti et al. 2019; Martin et al. 2012), moderation of the local climate (Ali \& Patnaik 2019; X. Chen et al. 2019;
Farrugia et al. 2013) and other beneficial services. Based on this background, Yogyakarta City is an appropriate case study for the research.

The research method used is a combination of: (1) Satellite Imagery Processing and Spatial Analysis, and (2) Simple Quantitative Analysis. The methods are described below.

\section{Satellite Imagery Processing and Spatial Analysis}

The method used to obtain tree canopy data is through a high-resolution satellite imagery processing. The higher the resolution of an image, the more detailed and accurate the quality of the processing results (Godinho, Guiomar, \& Gil 2018; McGee et al. 2012; Parmehr et al. 2016). Tree canopy data are generated from high-resolution satellite imagery with a spatial resolution of $0.44 \mathrm{~m}$. Images with this resolution can provide sharp and clear images so that they are suitable for use as the materials for identifying urban tree canopies. Furthermore, the image is processed using the Envi Map application. The result of the identification of the canopy is a raster format map which is then converted into polygon shapefile format.

We apply a multi-spectral classification with a supervised classification analysis type as well as a maximum likelihood feature. This technique is effective and straightforward in identifying tree canopies in large-scale areas such as cities or wider (Bravo-Bello, Martinez-Trinidad, Valdez-Lazalde, Romero-Sanchez \& Martinez-Trinidad 2020; Ossola \& Hopton 2018). Moreover, the classes used in this classification include tree canopies, grass, open land, buildings, roads, and bodies of water. From the identification results, then the tree canopy polygons are separated for further analysis, the illustration of the tree canopy identification results can be seen in Figure 1. below.

Furthermore, spatial analysis is applied to calculate the size and the distribution of tree canopy according to district administrative boundaries. The spatial analysis used is simple, i.e. 1) 'intersect' between tree canopy polygons and district administrative boundaries, 2) 'calculate geometry' to obtain the size of tree canopy per district. The results of this spatial analysis were used in the second step, which is simple quantitative analysis.
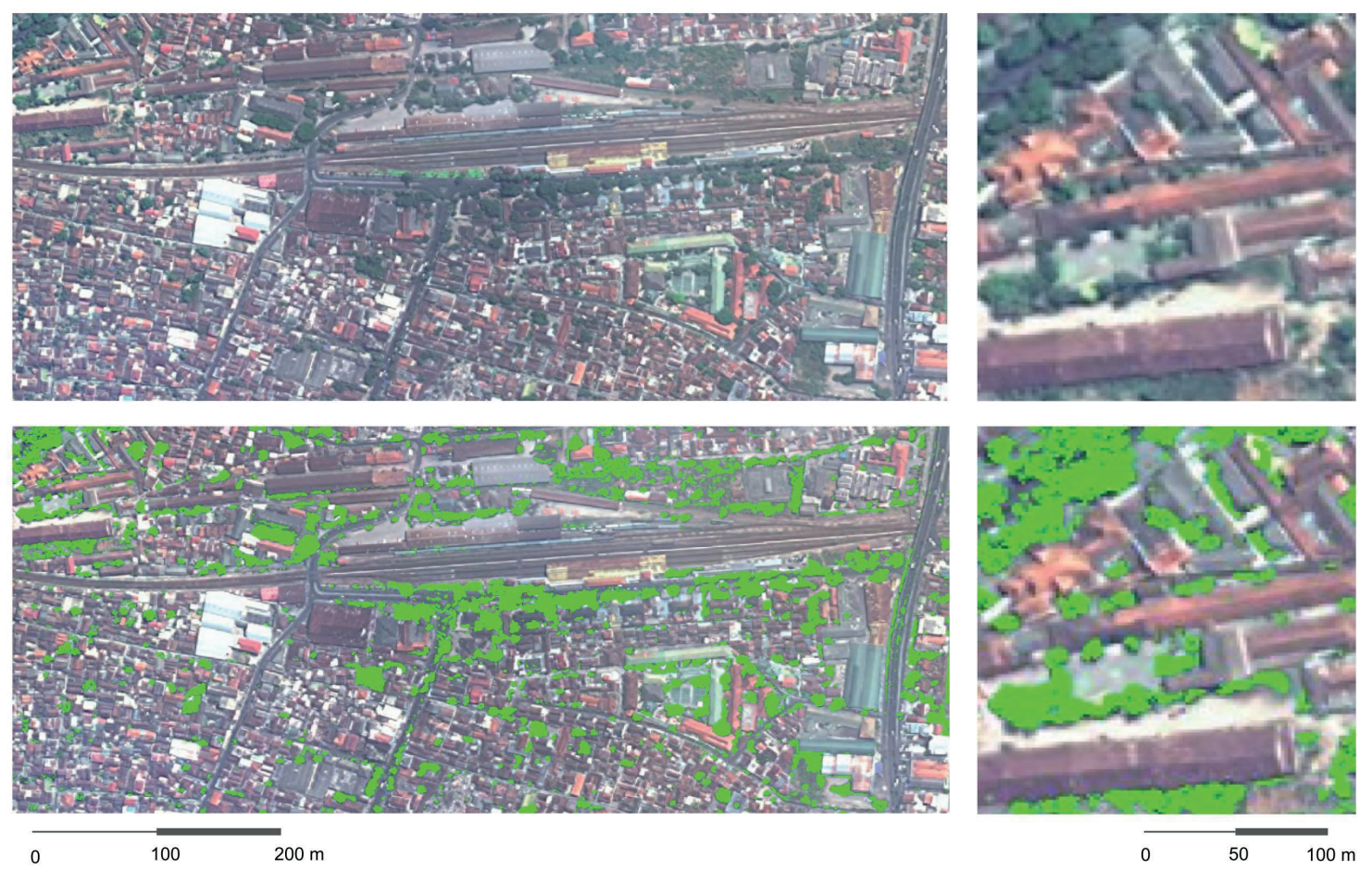

Fig. 1. Illustration of Canopy Identification Method 


\section{Simple Quantitative Analysis}

The simple quantitative analysis carried out includes 1) calculating the canopy cover percentage in the district area, and 2) calculating the canopy per capita for each district to assess its sufficiency based on the UN standard of $15 \mathrm{sqm} /$ person.

The canopy cover percentage is used to compare canopy cover in different boundary sizes (Campagnaro, Sitzia, Cambria, \& Semenzato 2019) such as cities, sub-districts / suburbs, even neighbourhoods. The smaller the canopy cover percentage in an area means that there is less surface covered by tree canopy, which results in a lower greenness level (Seiferling, Naik, Ratti, \& Proulx 2017). This condition has the same consequences for the ecosystem services that trees can provide, the smaller the canopy cover percentage; as a result, the smaller the ecosystem services provided by urban trees (McGovern \& Pasher 2016). Then, to calculate the rate of canopy cover in the area, a simple formula is used:

$\%$ Can $=[\mathrm{CanS}(\mathrm{Ha}) /$ Area $(\mathrm{Ha})] \times 100$

\%Can : percentage of canopy for each district

CanS $(\mathrm{Ha})$ : tree canopy size in hectares within the districts Area $(\mathrm{Ha})$ : district size in hectares

The second indicator used is canopy per capita, which is a proxy used to measure the likelihood of residents access to natural components such as trees (UN HABITAT 2016). The literature states that the interaction between humans and nature is important due to various benefits such as maintaining the mental and physical health of city residents (Fineschi \& Loreto 2020; Greene, Robinson \& Millward 2018; Soga \& Gaston 2020). Rest on this concept, the article argues that the greater the number of canopy per capita, the more likely it is for the public to access and gain socio-cultural benefits from urban trees. To calculate the canopy size per capita for each district, the following formula is used (UN HABITAT 2016):

Can/Cap $=[$ Cans (sqm) / Pop]

Can/Cap : canopy per capita for each district

CanS (sqm) : tree canopy sizes in sqm within district

Pop : total population per district

The study also estimates potential carbon sequestration per year and total potential carbon storage of canopy. To estimate potential carbon sequestration and storage of urban tree canopy, we follow numbers of carbon sequestration and storage of urban trees from a previous study (Nowak, Greenfield, Hoehn, \& Lapoint 2013). The previous study take U.S. cities as case for their research. They found that the net carbon sequestration of urban trees is $0.226 \mathrm{~kg} / \mathrm{m}^{2} /$ year and the total carbon storage is $7.69 \mathrm{~kg} / \mathrm{m}^{2}$. Then, the following formula are used:
CarbonSeq $=$ Netseq $\times$ CanS (sqm)

where,

CarbonSeq : estimated potential carbon sequestration of urban tree canopy per year

Netseq : $0.266 \mathrm{~kg} / \mathrm{m}^{2} /$ year

CanS (sqm) : tree canopy sizes in sqm within district and

CarbonStor $=$ Stor $\times$ CanS (sqm)

CarbonStor : estimated potential carbon sequestration of urban tree canopy in total

Stor : $7.69 \mathrm{~kg} / \mathrm{m}^{2}$

CanS (sqm) : tree canopy sizes in sqm within the district

It is important to note that the estimation in this study is not a direct measurement. It aims to illustrate rough estimation of urban tree canopy potential to support climate change mitigation. For this reason, further estimation with a more sophisticated method may be needed.

\section{RESULTS}

The research used three indicators to measure the level of the greenness of a city and its distribution between districts. The first is the canopy size. The canopy size is the most basic data generated from the spatial analysis. The second information is the canopy cover percentage that compares the canopy size to districts size. The third information is the canopy area per capita calculated by dividing the canopy size by the number of people living in the area. The findings of each information are described as follows.

\section{Canopy Size}

The analysis results show that the total canopy size of Yogyakarta is $467.37 \mathrm{Ha}$. Also, when using actual canopy size data in each district, the tree canopy size distribution ranges from $6.46 \mathrm{Ha}-134.19 \mathrm{Ha}$. Umbulharjo is the district with the widest canopy (134.19 ha) and Pakualaman hase the smallest canopy size (6.46 ha). The detailed pattern of canopy size distribution per district can be seen in Table 2. Of the 14 districts, the average number of canopy size is $33.38 \mathrm{Ha}$, and the mean value is $21.92 \mathrm{Ha}$. The size of each district relates to the size of the district boundaries. Based on the size of the district, Umbulharjo is the largest district (812 hectares), and Pakualaman is the district with the smallest size (63 hectares). The rankings that appear in canopy size have a similarity to the order of district boundaries size (See Figure 2 for a graph illustrating this pattern). Therefore, it was concluded that canopy size data could provide an initial depiction of the existence and distribution of tree canopies. Still, the information cannot be the only benchmark in assessing the level of the greenness of an area. Consequently, further information is needed, such as the percentage of canopy and canopy cover per capita.

Table 1. Data and Sources

\begin{tabular}{|c|c|c|c|}
\hline No. & Data & Function & Sources \\
\cline { 1 - 3 } 1 & Yogyakarta Satellite Imagery 2018 & $\begin{array}{c}\text { For classifying and identifying tree canopy. The classification } \\
\text { results are then converted into tree canopy polygons. }\end{array}$ & $\begin{array}{c}\text { Yogyakarta Land and Spatial } \\
\text { Planning Board }\end{array}$ \\
\cline { 1 - 3 } 2 & District Administrative Boundary & As a unit of analysis and visualisation & \multirow{2}{*}{$\begin{array}{c}\text { Yogyakarta in Figures } \\
\text { (Statistics Board) }\end{array}$} \\
\cline { 1 - 3 } & The population of 2018* & Calculation of population density and canopy per capita \\
\hline
\end{tabular}




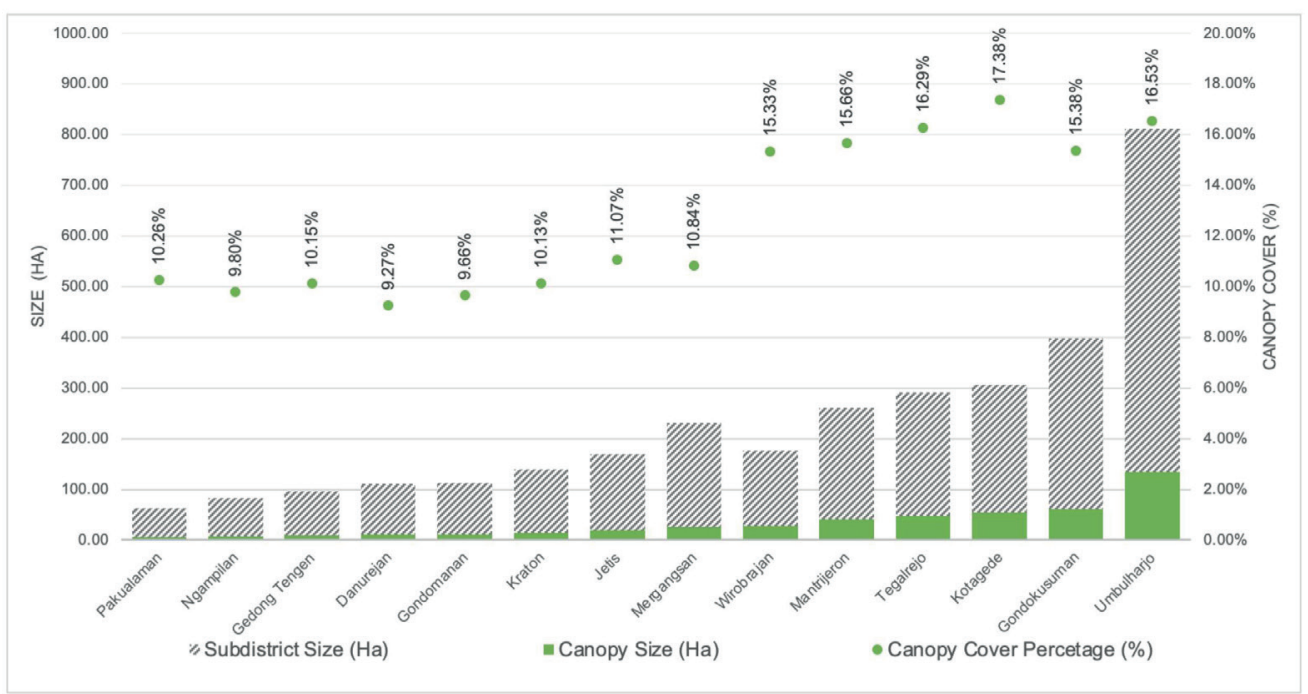

Fig. 2. Canopy size and Canopy Cover Percentage

\section{Canopy Cover Percentage}

The canopy cover percentage is obtained by dividing the canopy size by the size of an area (district). The canopy cover percentage in Yogyakarta City currently only reaches $14.38 \%$ or $467.37 \mathrm{Ha}$ of the total size of Yogyakarta City of 3,249.31 Ha. If we compare the canopy cover percentage in Yogyakarta with several noteworthy green cities in the world (Liu \& Jensen 2018), the canopy cover in Yogyakarta is relatively low. For example, Singapore has a canopy cover percentage of $29.3 \%$ and Geneva has $21.4 \%$ (data source: Treepedia; methods used see (Li et al. 2015; Seiferling et al. 2017)). There is also Melbourne with an actual canopy cover rate of $22 \%$ and a target of increasing the canopy of up to $40 \%$ by 2040 (City of Melbourne 2012). A brief look at these cities provides an overview of the direction of the tree canopy policy that Yogyakarta City needs to formulate, namely the protection and addition of urban tree canopies.

Next is the canopy cover percentage at the district level. The results of the calculation of the canopy cover percentage in the districts of Yogyakarta ranged from 9.27\% - 17.38\% with an average number of $12.70 \%$ (see Table 2). Based on the canopy cover percentage, there is a similar trend even though there has been a slight change in the ranks (see Figure 2 for a graph that illustrates it). The district with the most extensive canopy cover is Kotagede with $17.38 \%$ covering the area. Umbulharjo, which has the largest canopy size, was in second place for the canopy cover percentage with $16.53 \%$.
The district with the lowest rate of canopy cover is Danurejan with $9.27 \%$. It is observed that the level of greenness in the city of Yogyakarta is not evenly distributed to each district (see Figure 4).

\section{Canopy per Capita}

Using population data in 2018, the canopy per capita in Yogyakarta City is $10.93 \mathrm{sqm} /$ person. This number is still below the standard set by the UN, which is $15 \mathrm{sqm} /$ person (UN HABITAT, 2016) hence requiring an escalation of about 4.07 sqm/person (See Figure 3). If we look at the data at the district level, the rate of canopy per capita in Yogyakarta ranges from $4.69 \mathrm{sqm} /$ person - $14.45 \mathrm{sqm} /$ person. This means that all districts in Yogyakarta City have canopy per capita number below the UN recommendation. In Figure 3, a graph of the distribution of canopy per capita for each district is presented as well as the additional gaps that can be potentially added. The district with the lowest canopy per capita was Ngampilan (4.69 sqm/person), and the district with the most extensive canopy per capita was Umbulharjo (14.45 sqm/person). The spatial distribution pattern can be seen on the map contained in Figure 4. Moreover, based on the data from 14 districts, it is obtained an average value of $9.29 \mathrm{sqm} /$ person and a mean value of $8.10 \mathrm{sqm} /$ person. All of the information indicates that there is still a lack of canopy size in Yogyakarta City to facilitate access and interactions of residents with natural components such as trees.

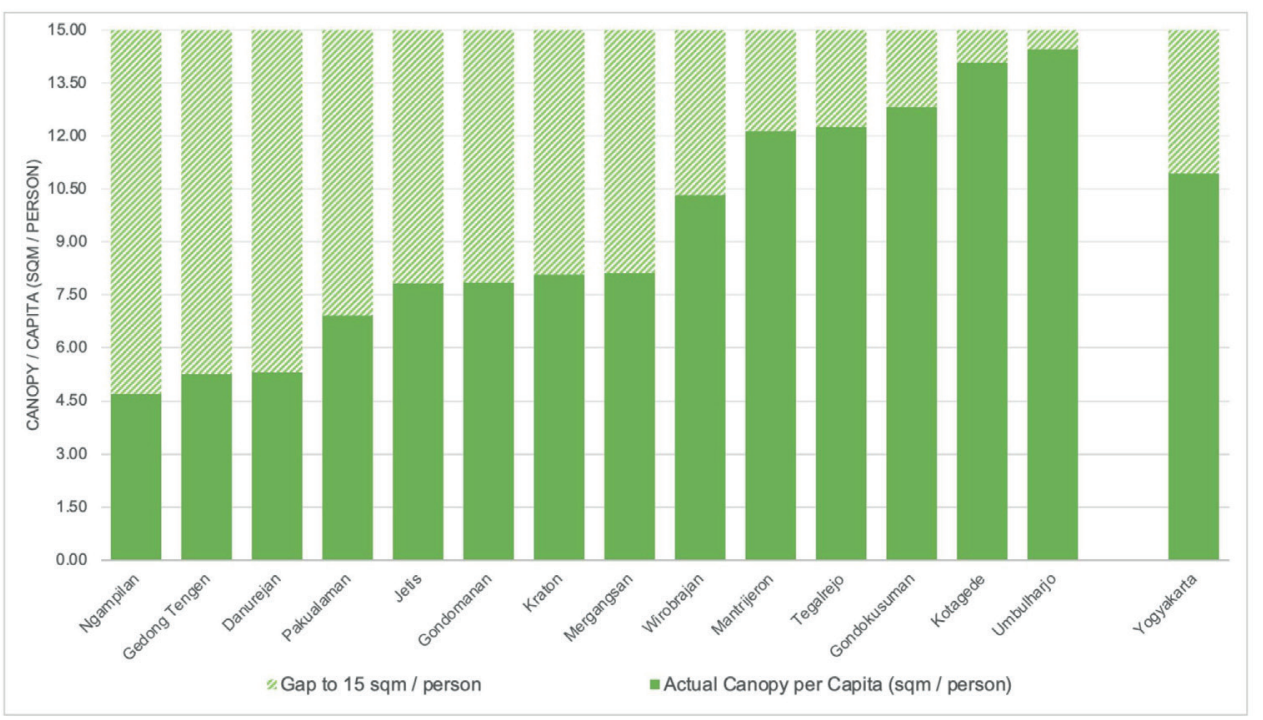

Fig. 3. Canopy per Capita and the Gap 


\section{Potential Carbon Sequestration and Storage}

The study also analyse a rough estimation of carbon sequestration and storage of urban trees. The finding simply shows that the larger the size of canopy cover, the larger the potential number of carbon absrobed and stored by urban trees. Based on the estimation, the largest potential carbon sequestration is in Umbulharjo (303.45 t C / year) and the lowest potential carbon storage is in Pakualaman (14.61 t C / year). The total city-level potential carbon sequestration is $1,056.25 \mathrm{tC} /$ year, while the average carbon sequestration is $75.45 \mathrm{t} \mathrm{C} \mathrm{/} \mathrm{year} \mathrm{and} \mathrm{the} \mathrm{median} \mathrm{is} 49.55 \mathrm{t} \mathrm{C} \mathrm{/} \mathrm{year.} \mathrm{In} \mathrm{addition,}$ city-level potential carbon storage is $35,940.44 \mathrm{t} C$ while the average is $2,567.17 \mathrm{t} \mathrm{C}$ and the median is 1,685.90 t C. Table 2 column I and J provide detailed estimation of carbon sequestration and storage for all districts.

\section{DISCUSSION}

\section{Strengths and Weaknesses of Indicators}

This research uses three different types of information to measure the greenness level of a city, namely the canopy size, the canopy cover percentage, and canopy per capita. Cities authority may use the information as one of indicators to measure achievement of SDGs, especially for Goals 11, 13, and 15 (Turner-Skoff \& Cavender 2019). The three types of information have their respective strengths and weaknesses in measuring the greenness of a city. The strengths and weaknesses identified by the authors are presented in Table 3.

\section{Policy Implications}

The article discusses policy recommendations into two parts: the first part is the general policy implications for cities in Indonesia; the second part is the policy implications that specifically targets Yogyakarta City as the case study used in this research. The first is related to policy recommendations for cities in Indonesia. The results of this research indicate that Yogyakarta City has a relatively low level of greenness based on information on canopy size, canopy cover percentage, and canopy per capita. This condition is likely to occur in other Indonesian cities (Ramdhoni, Rushayati \& Prasetyo 2016). In Indonesia, the current green infrastructure policy framework only regulates mandatory size for green open space in urban areas. It mandates urban areas to have at least 30\% open space, consisting of $20 \%$ public open space and $10 \%$ private open space. Additionally, in terms of urban trees, there is a policy guideline that helps local authorities to increase urban greeneries with various green open space design and planning strategies. The guideline, however, does not integrate the urban tree preservation with other urban development permit schemes. In addition, the absence of urban tree management policy plays a significant role in the decreased numbers of urban trees (Guo et al. 2019; Nowak \& Greenfield 2018; Phelan et al. 2019). This article recommends a policy framework for better urban trees planning and management in Indonesian cities that integrate urban trees preservation, technology, and permit schemes (See Figure 5).

Accordingly, the first recommendation in this research is that there is a need for similar studies to assesses the

Table 2. Canopy Distribution in Yogyakarta City

\begin{tabular}{|c|c|c|c|c|c|c|c|c|c|}
\hline A & B & C & D & E & F & G & $\mathrm{H}$ & I & J \\
\hline District & $\begin{array}{c}\text { Area Size } \\
\text { (ha) }\end{array}$ & $\begin{array}{l}\text { Population } \\
\text { (2018) }\end{array}$ & $\begin{array}{l}\text { Population } \\
\text { Density / ha }\end{array}$ & $\begin{array}{l}\text { Canopy } \\
\text { size (ha) }\end{array}$ & $\begin{array}{c}\text { Canopy size } \\
\text { (sqm) }\end{array}$ & $\begin{array}{c}\text { Canopy } \\
\text { cover } \\
\text { percentage } \\
(\%)\end{array}$ & $\begin{array}{c}\text { Canopy } \\
\text { per } \\
\text { capita } \\
\text { (sqm/ } \\
\text { person) }\end{array}$ & $\begin{array}{l}\text { Potential } \\
\text { Carbon } \\
\text { Sequestration } \\
\text { (t C/year) }\end{array}$ & $\begin{array}{c}\text { Potential } \\
\text { Carbon } \\
\text { Storage } \\
\text { (t C) }\end{array}$ \\
\hline Formula & Area & Pop & Pop/Area & Cans $(\mathrm{Ha})$ & CanS (sqm) & $\begin{array}{c}\text { Cans / Area } \\
\times 100\end{array}$ & $\begin{array}{l}\text { Cans } \\
\text { (sqm)/ } \\
\text { Pop }\end{array}$ & $\begin{array}{c}\text { netseq } \times \text { Cans } \\
(\text { sqm) }\end{array}$ & $\begin{array}{l}\text { Stor } x \\
\text { Cans } \\
(\text { sqm) }\end{array}$ \\
\hline Ngampilan & 82.00 & 17,117 & 208.74 & 8.03 & $80,346.46$ & $9.80 \%$ & 4.69 & 18.16 & 617.86 \\
\hline Gedong Tengen & 96.00 & 18,546 & 193.19 & 9.74 & $97,399.06$ & $10.15 \%$ & 5.25 & 22.01 & 749.00 \\
\hline Danurejan & 110.31 & 19,223 & 174.26 & 10.22 & $102,207.24$ & $9.27 \%$ & 5.32 & 23.10 & 785.97 \\
\hline Pakualaman & 63.00 & 9,336 & 148.19 & 6.46 & $64,634.69$ & $10.26 \%$ & 6.92 & 14.61 & 497.04 \\
\hline Kraton & 140.00 & 17,575 & 125.54 & 14.19 & $141,870.49$ & $10.13 \%$ & 8.07 & 32.06 & $1,090.98$ \\
\hline Jetis & 170.00 & 24,036 & 141.39 & 18.81 & $188,123.27$ & $11.07 \%$ & 7.83 & 42.52 & $1,446.67$ \\
\hline Gondomanan & 112.00 & 13,781 & 123.04 & 10.82 & $108,176.14$ & $9.66 \%$ & 7.85 & 24.45 & 831.87 \\
\hline Mergangsan & 231.00 & 30,836 & 133.49 & 25.03 & $250,342.07$ & $10.84 \%$ & 8.12 & 56.58 & $1,925.13$ \\
\hline Wirobrajan & 176.00 & 26,134 & 148.49 & 26.98 & $269,817.42$ & $15.33 \%$ & 10.32 & 60.98 & $2,074.90$ \\
\hline Mantrijeron & 261.00 & 33,688 & 129.07 & 40.88 & $408,802.07$ & $15.66 \%$ & 12.13 & 92.39 & $3,143.69$ \\
\hline Tegalrejo & 291.00 & 38,691 & 132.96 & 47.41 & $474,066.63$ & $16.29 \%$ & 12.25 & 107.14 & $3,645.57$ \\
\hline Kotagede & 307.00 & 37,937 & 123.57 & 53.37 & $533,698.02$ & $17.38 \%$ & 14.07 & 120.62 & $4,104.14$ \\
\hline Umbulharjo & 812.00 & 92,867 & 114.37 & 134.19 & $1,341,925.62$ & $16.53 \%$ & 14.45 & 303.28 & $10,319.41$ \\
\hline Gondokusuman & 398.00 & 47,731 & 119.93 & 61.23 & $612,250.24$ & $15.38 \%$ & 12.83 & 138.37 & $4,708.20$ \\
\hline Average (Mean) & & & & 33.38 & $333,832.82$ & $12.70 \%$ & 9.29 & 75.45 & $2,567.17$ \\
\hline Median & & & & 21.92 & $219,232.67$ & $10.95 \%$ & 8.10 & 49.55 & $1,685.90$ \\
\hline City Level & $3,249.31$ & $427,498.00$ & 131.57 & 467.37 & $4,673,659.42$ & $14.38 \%$ & 10.93 & $1,056.25$ & $35,940.44$ \\
\hline
\end{tabular}



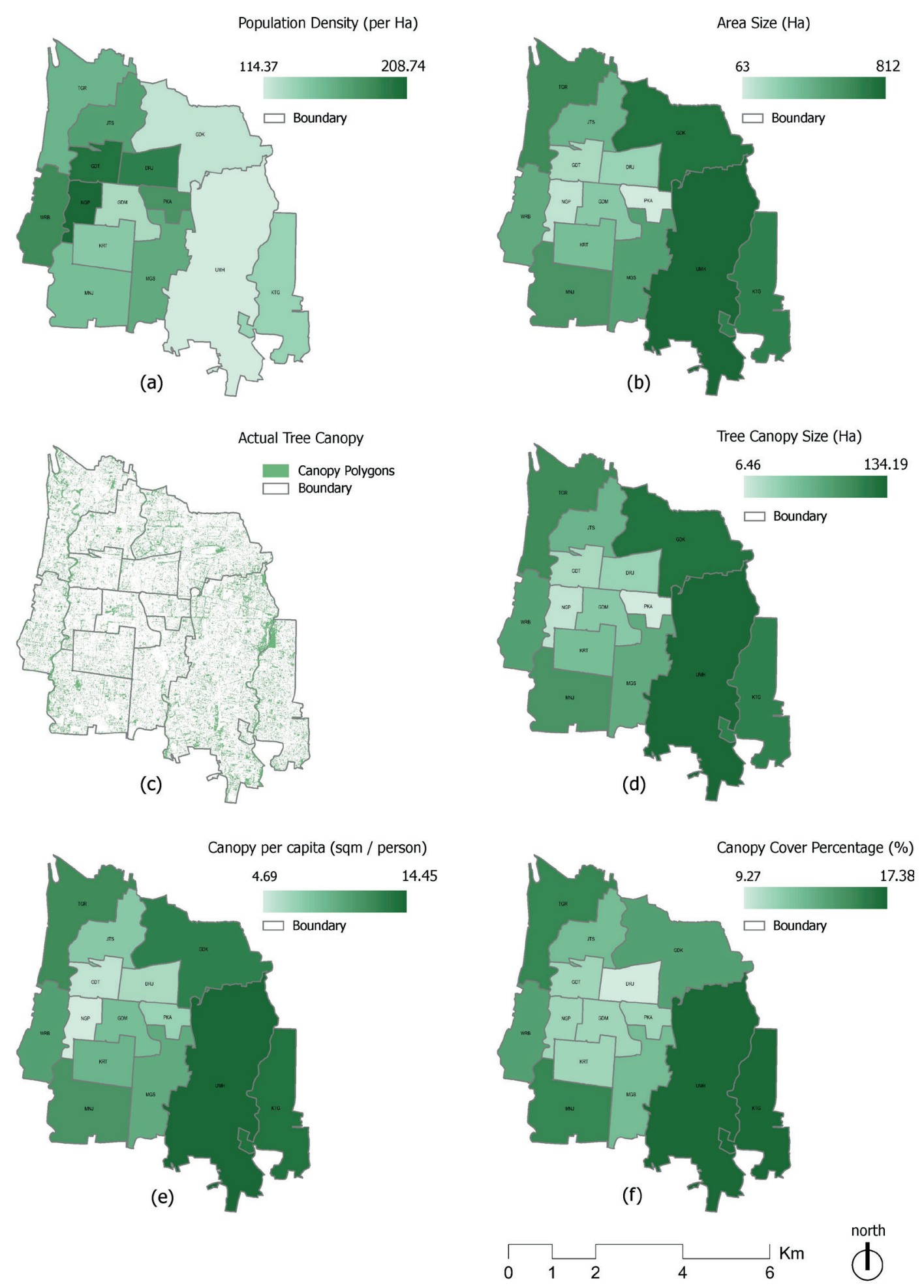

Fig. 4. (a) Population density; (b) Sizes of the districts; (c) Actual tree canopy polygons; (d) Tree canopy size per districts; (e) Canopy per capita; (f) Canopy cover percentage. Details in numbers are presented in Table 2

existence of urban tree canopy in Indonesian cities. baseline information regarding the presence of urban trees is required to formulate more effective policies for managing urban trees and its ecosystem services (Intasen et al. 2017; McGee et al. 2012; Parmehr et al. 2016) that can contribute to create more sustainable Indonesian cities. Further studies on urban trees in Indonesian cities may also add more detailed information such as the types, losses, gain, key ecosystem services, even health status of the trees.

The second recommendation is that urban trees should be put as the priority development programs and activities. It aims to increase the level of the greenness of cities in Indonesia asI well as to achieve SDGs Goal 11,13, and 15. This recommendation can be adopted by agencies in charge of the environment and open space sector. Accordingly, business as usual policies related to urban trees need to be transformed into more innovative approaches to preserve and increase the existence of urban trees (Trees \& Design Action Group 2012, 2014). For example, by integrating the control and conservation of urban trees with zoning regulations (Davey Resource Group 2015; Phelan et al. 2019), construction permits (Guo et al. 2019; Morgenroth, O'Neil-Dunne, \& Apiolaza 2017), and development permits as exemplified in many other cities in the world (Hilbert et al. 2019; Lavy \& Hagelman 2017, 2019). At the same time, programs and activities to grow more trees also need to be implemented in a visionary and measurable way. The City of Melbourne, for instance, created an 'Urban Forest 
Strategy' which includes a series of long-term oriented programs and actions accompanied by regular monitoring and evaluation (City of Melbourne 2012). One of their targets is to achieve 40\% canopy cover percentage in public realms which must be completed by 2040 along with various annual programs and activities to achieve this target. Another example comes from Singapore that plans urban forestry rehabilitation that covers every scale and land use types such as protected natural area, streetscapes, parks, even vacant lands (Davison 2005) and applying the biophilic concept to their urban environments (Singapore National Parks Board, accessed on August 2020)

The third recommendation is an engagement of stakeholders which is also an essential aspect of urban tree management (Brunner \& Cozens 2013; Drillet et al. 2020; Papastavrou 2019; Trees \& Design Action Group 2014). As explained above that protection of trees needs to be integrated into land-use permit schemes such as zoning, construction and development permits. As every stakeholders have roles in protecting and even increasing the number of urban trees, it is necessary to involve a variety of stakeholders. Those stakeholders include government as the policymaker, regulator, and license issuer (Lavy \& Hagelman 2019; van der Jagt \& Lawrence 2019), contractors and developers as parties carrying out physical construction (Guo et al. 2018; Morgenroth et al. 2017; Phelan et al. 2019), as well as city residents as private land owners (Conway 2016; Davis \& Jones 2014).

The implications of the second policy are specifically addressed for the City of Yogyakarta. First, this research finds a pattern that the level of greenness in the city centre area is relatively lower, as indicated by the canopy size and the lower percentage of canopy cover. They are Ngampilan, Danurejan, Pakualaman, Keraton, Gedongtengen, Gondomanan (see Figure 4 and Table 2 for details). These districts have lower tree canopy due to rapid physical development and population growth that led to urban trees removal. The population density map (Figure 4 (a)) demonstrates that these areas have relatively higher population density that other districts. According to the existing land use, the areas are also dominated by built-up uses such as housing, commercial and services, as well as industries. Besides, an absence of urban tree demolition permits in the city is one of the potential causes of urban trees shortage.
Thus, the local authority can prioritise those areas for trees planting sites, to increase canopy size and the percentage of tree canopy cover. As stated in a previous study that increasing the canopy size and canopy cover percentage can increase aesthetics (Conway 2016), while simultaneouslyproviding more ecosystem services to the city. Those ecosystem services include reducing pollution (Ferranti et al. 2019; Martin et al. 2012), providing thermal comfort (Ali \& Patnaik 2019; X. Chen et al. 2019; Farrugia et al. 2013), reducing the potential for flooding (Y. Chen \& Borelli 2016; Farrugia et al. 2013; Pappalardo et al. 2017), even absorbing carbon and helping to mitigate climate change (McGovern \& Pasher 2016; Russo et al. 2014; Tang et al. 2016).

In this second part, the findings show that all districts in Yogyakarta City have a canopy per capita below the UN recommendation rate of $15 \mathrm{sqm} /$ person. This condition indicates the low likelihood of residents interacting with the urban green component. A city should ideally be able to accommodate its residents to interact with nature. With a relatively dynamic population and an increasing trend, keeping pace with population growth and development activities with urban tree planting (to grow the canopy per capita) is a strategic policy recommendation for the City of Yogyakarta. The priority of adding trees can be directed at districts with a small canopy per capita (for example, below $10 \mathrm{sqm} /$ person) so city residents can have more even access to tree canopies. The second priority is to grow the number of canopy per capita in districts that are already close to the UN recommendation rate. That way the distribution of the canopy per capita will be more even. The even distribution of the canopy provides equal access for residents to interact with urban trees. The interaction of city residents with environmental elements such as trees can maintain the mental and physical health of residents (Fineschi \& Loreto 2020; Greene et al. 2018; Soga \& Gaston 2020). The interaction between residents and trees can also enhance understanding and knowledge about environmental conservation, especially in the protection of urban trees (Davis \& Jones 2014).

\section{Limitations and Potential for Future Research}

This research acknowledges several weaknesses that can be improved in further research. Firstly, as by aiming

\section{Urban Trees Planning \& Management Policy Framework}

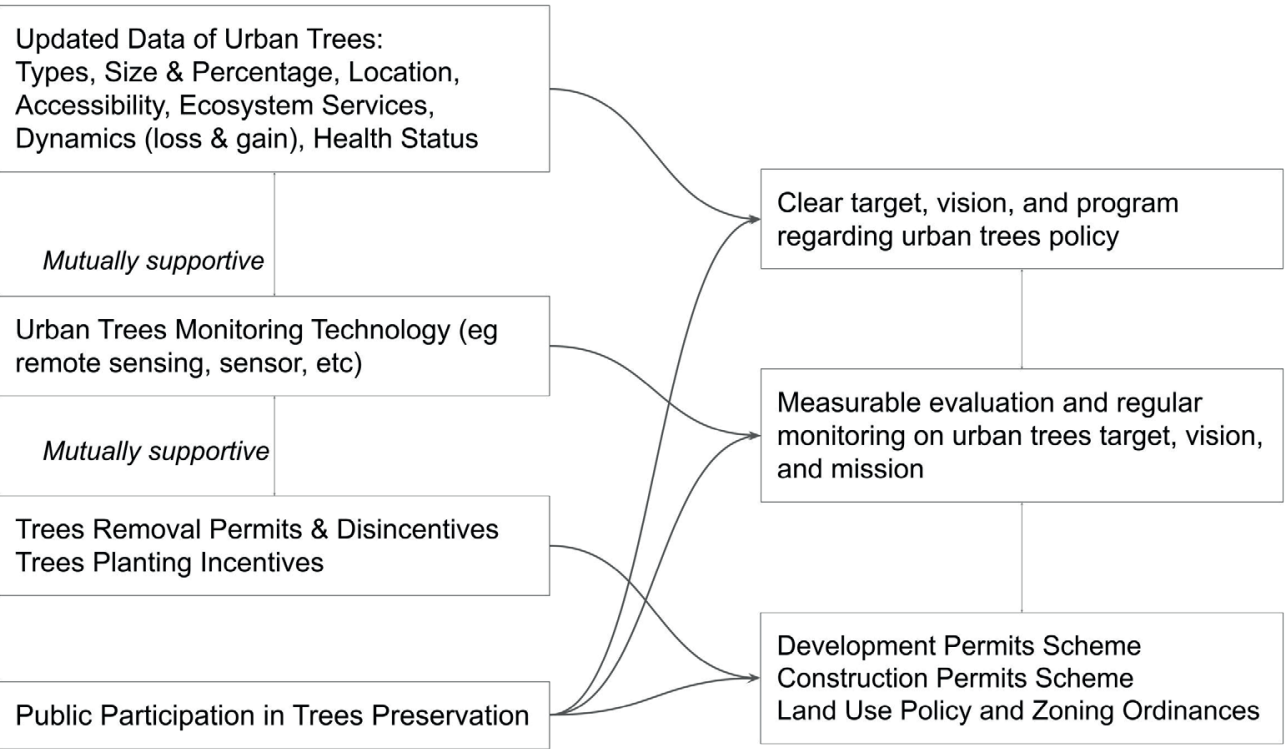

Fig. 5. Urban Trees Planning and Management Policy Framework 
Table 3. Weaknesses, Strengths, and Recommendations for Usage

\begin{tabular}{|c|c|c|c|c|}
\hline Type of Information & Data Needed & Strength & Weakness & Recommended Usage \\
\hline Canopy size & Only canopy size & $\begin{array}{l}\text { Provides preliminary } \\
\text { information on the extent } \\
\text { and distribution of canopy } \\
\text { displayed in data by area } \\
\text { (district or smaller) }\end{array}$ & $\begin{array}{c}\text { Using only the canopy size } \\
\text { can cause bias in assessing } \\
\text { the level of greenness } \\
\text { because the canopy size } \\
\text { can be affected by the size } \\
\text { of the area }\end{array}$ & $\begin{array}{l}\text { As an initial data inventory } \\
\text { for further analysis }\end{array}$ \\
\hline $\begin{array}{l}\text { Canopy cover } \\
\text { percentage }\end{array}$ & $\begin{array}{l}\text { 1. Canopy size } \\
\text { 2. Area / Boundary Size }\end{array}$ & $\begin{array}{c}\text { The percentage unit } \\
\text { allows a fairer way to } \\
\text { compate greenery levels } \\
\text { between areas }\end{array}$ & $\begin{array}{l}\text { Data characteristics tend } \\
\text { to be static, especially in } \\
\text { the size component. Static } \\
\text { data potentially influences } \\
\text { business-as-usual policy } \\
\text { formulation }\end{array}$ & $\begin{array}{l}\text { 1. To compare the level of } \\
\text { greenness between areas } \\
\text { (such as districts, sub- } \\
\text { districts, neighbourhoods) } \\
\text { 2. As input for regulating } \\
\text { ecosystem services, } \\
\text { such as local climate } \\
\text { moderation (such as } \\
\text { thermal comfort / } \\
\text { reducing urban heat } \\
\text { island) and stormwater } \\
\text { run-off regulation }\end{array}$ \\
\hline $\begin{array}{l}\text { Canopy Per capita } \\
\text { (sqm/person) }\end{array}$ & $\begin{array}{l}\text { 1. Canopy size } \\
\text { 2. Total Population }\end{array}$ & $\begin{array}{l}\text { Describes the socio- } \\
\text { environmental aspects } \\
\text { and serves as an } \\
\text { approach in measuring } \\
\text { the accessibility of urban } \\
\text { residents to interact with } \\
\text { the natural components of } \\
\text { the city (trees) }\end{array}$ & $\begin{array}{l}\text { With its dynamic } \\
\text { characteristics especially } \\
\text { on the components of the } \\
\text { population, the indicator } \\
\text { requires an adjustment } \\
\text { of the target every year. } \\
\text { Assessment activities also } \\
\text { need to be an annual } \\
\text { routine }\end{array}$ & $\begin{array}{l}\text { 1. To measure the } \\
\text { accessibility of residents' } \\
\text { interactions with natural } \\
\text { components, especially } \\
\text { urban trees } \\
\text { 2. As an approach for } \\
\text { analysis related to cultural } \\
\text { ecosystem services, } \\
\text { such as recreation and } \\
\text { inspiration }\end{array}$ \\
\hline $\begin{array}{c}\text { Potential Carbon } \\
\text { Sequestration and } \\
\text { Storage }\end{array}$ & $\begin{array}{l}\text { 1. Canopy size } \\
\text { 2. Carbon sequestration } \\
\text { ability } \\
\text { 3. Carbon storage ability } \\
\text { For direct measurement, } \\
\text { more data may be needed } \\
\text { such as tree species, size, } \\
\text { old, etc }\end{array}$ & $\begin{array}{l}\text { Describes the climate } \\
\text { change mitigation } \\
\text { potential of urban trees } \\
\text { to further influence urban } \\
\text { tree preservation and } \\
\text { urban environmental } \\
\text { policies. }\end{array}$ & $\begin{array}{l}\text { Direct measurement of } \\
\text { carbon sequestration and } \\
\text { storage of urban trees } \\
\text { need more sophisticated } \\
\text { methods, detailed data, } \\
\text { and larger samples. }\end{array}$ & $\begin{array}{l}\text { 1. To understand the } \\
\text { current state of urban } \\
\text { trees'ability in mitigating } \\
\text { climate crisis } \\
\text { 2. As the baseline data for } \\
\text { carbon offset scheme }\end{array}$ \\
\hline
\end{tabular}

for a baseline assessment, this research does not use spatio-temporal data. To get temporal data of canopy, high-resolution satellite images from the past years are necessary (Ellis \& Mathews 2019). By using temporal data, the information obtained can include the dynamics of the presence of the canopy (Ossola \& Hopton 2018). In other words, the research can identify information regarding the gains and losses of the canopy and the area where canopy gains and losses occur (Davey Resource Group 2015; Ellis \& Mathews 2019; McGovern \& Pasher 2016). Besides, by using spatio-temporal data, the loss of ecosystem services resulting from declined tree canopy size can also be estimated (McGovern \& Pasher 2016; Riley \& Gardiner 2020). By estimating ecosystem services, strategies to protect or even increase the number of trees in urban areas can be formulated effectively based on evidence (evidencebased policy). Secondly, cross-sectoral analysis is also recommended for future research in urban tree canopy field, especially in Indonesian cities context. For instance, future research may link canopy cover data with sociodemographic characteristics (Hostetler, Rogan, Martin, Delauer, \& Oneil-Dunne 2013; Lavy \& Hagelman 2017), with development policies, as well as land-use dynamics (Davey Resource Group 2015; Ellis \& Mathews 2019; Phelan et al. 2019). Future research can also utilise spatial modelling to identify a potential area for tree planting. Possible methods include multi-criteria analysis based on remote sensing and GIS (geographic information systems)(Bravo-Bello et al. 2020; Davey Resource Group 2015). Lastly, future research may also combine tree canopy assessment and more sophisticated methods in directly estimating potential carbon sequestration and carbon storage (McGovern \& Pasher 2016) in order to assist cities in taking a role in mitigating climate crisis (Bayulken, Huisingh, \& Fisher 2021; Frantzeskaki 2019; Petri, Wilson, \& Koeser 2019).

\section{CONCLUSIONS}

This research has measured the level of the greenness of an Indonesian city by using the presence and distribution of urban tree canopy. The methods used in this research are remote sensing, spatial analysis, and simple quantitative analysis. The spatial distribution of the tree canopy has been identified identified and analysed. From the urban tree canopy data, we present three types of information, namely: 1) canopy size for assessing the existence of tree canopy, 2) the canopy cover percentage for assessing distribution and equality of tree canopy, and 3) the number of canopy per capita as a proxy for assessing the accessibility of residents to interact with nature.

The findings show that the total canopy size of the city of Yogyakarta is only 467.37 hectares. The tree canopy size distribution per district ranges from $6.46 \mathrm{Ha}-134.19 \mathrm{Ha}$. Of the 14 districts, the average canopy size number is 33.38 
$\mathrm{Ha}$, and the median value is $21.92 \mathrm{Ha}$. Next, the percentage of canopy cover in Yogyakarta is only $14.38 \%$ covering the area of the city. If we look at the districts level, the canopy cover percentage in districts in Yogyakarta ranges from $9.27 \%-17.38 \%$ of the area. This number is relatively lower compared to green cities in the world, such as Singapore and Melbourne. Additionally, this research found that the number of canopy per capita in Yogyakarta City is still below the UN recommendation rate of $15 \mathrm{sqm} /$ person. The canopy per capita rates in the Yogyakarta districts are only around $4.69 \mathrm{sqm} /$ person - $14.45 \mathrm{sqm} /$ person. These findings suggest that an integrated, visionary and measurable policy is needed to protect and to plant more trees in Yogyakarta strategically. Moreover, the three indicators used have strenghts and weaknesses in measuring the level of greenness. This research recommends the use of each indicator as follows: 1) canopy size information as an initial data inventory for further analysis, 2) Canopy cover percentage to measure and compare the levels of greenness spatially and visually between areas, 3) Canopy per capita is recommended to measure the possibility of access and interaction of residents with the presence of tree canopies. Cities' authority can also use the information to measure the achievement of SDGs number 11, 13, or 15

Finally, as a preliminary research this study proposes several recommended improvements for further research. First, following research may use temporal data to identify the dynamics of urban tree canopy from year to year. In addition, future studies may also utilise a more sophisticated spatial analysis such as multi-criteria site selection and modelling to identify new tree planting sites.

\section{REFERENCES}

Ali S.B. \& Patnaik S. (2019). Assessment of the impact of urban tree canopy on microclimate in Bhopal: A devised low-cost traverse methodology. Urban Climate, 27, 430-445, DOI: 10.1016/j.uclim.2019.01.004.

Aronson M.F.J., Lepczyk C.A., Evans K.L., Goddard M.A., Lerman S.B., Maclvor J.S. ... Vargo T. (2017). Biodiversity in the city: key challenges for urban green space management. Frontiers in Ecology and the Environment, 15(4), 189-196, DOI: 10.1002/fee.1480.

Bayulken B., Huisingh D. \& Fisher P.M.J. (2021). How are nature based solutions helping in the greening of cities in the context of crises such as climate change and pandemics? A comprehensive review. Journal of Cleaner Production, 288, 125569, DOI: 10.1016/j.jclepro.2020.125569. Bravo-Bello J.C., Martinez-Trinidad T., Valdez-Lazalde J.R., Romero-Sanchez M.E. \& Martinez-Trinidad S. (2020). Analyzing Potential TreePlanting Sites and Tree Coverage in Mexico City Using Satellite Imagery. Forests, 11(4), 423, DOI: 10.3390/f11040423.

Brunner J. \& Cozens P. (2013). 'Where Have All the Trees Gone?' Urban Consolidation and the Demise of Urban Vegetation: A Case Study from Western Australia. Planning Practice and Research, 28(2), 231-255, DOl: 10.1080/02697459.2012.733525.

Campagnaro T., Sitzia T., Cambria V.E. \& Semenzato P. (2019). Indicators for the Planning and Management of Urban Green Spaces: A Focus on Public Areas in Padua, Italy. Sustainability, 11(24), 7071, DOl: 10.3390/su11247071.

Chen X., Zhao P., Hu Y., Ouyang L., Zhu L. \& Ni G. (2019). Canopy transpiration and its cooling effect of three urban tree species in a subtropical city - Guangzhou, China. Urban Forestry and Urban Greening, 43(November 2018), 126368, DOl: 10.1016/j.ufug.2019.126368.

Chen Y. \& Borelli S. (2016). Towards a Greener, Healthier, and Happier Future. The 1st Asia-Pacific Urban Forestry Meeting. Retrieved from www.fao.org/forestry/urbanforestry.

City of Melbourne (2012). Urban Forest Strategy: Making a great city greener 2012-2032.

Conway T.M. (2016). Tending their urban forest: Residents' motivations for tree planting and removal. Urban Forestry and Urban Greening, 17, 23-32, DOI: 10.1016/j.ufug.2016.03.008.

Davey Resource Group (2015). City of Pacific Grove Urban Tree Canopy Assessment.

Davis K.L. \& Jones R.E. (2014). Modeling Environmental Concern for Urban Tree Protection Using Biophysical and Social Psychological Indicators. Society and Natural Resources, 27(4), 372-388, DOI: 10.1080/08941920.2013.861555.

Davison G. (2005). Urban forest rehabilitation - A case study from Singapore. Keep Asia Green: Volume I, South East Asia, (Corner 1978), 171-181.

Drillet Z., Fung T.K., Leong R.A.T., Sachidhanandam U., Edwards P. \& Richards D. (2020). Urban vegetation types are not perceived equally in providing ecosystem services and disservices. Sustainability (Switzerland), 12(5), DOI: 10.3390/su12052076.

Ellis E.A. \& Mathews A.J. (2019). Object-based delineation of urban tree canopy: assessing change in Oklahoma City, 2006-2013. Computers, Environment and Urban Systems, 73(August 2018), 85-94, DOI: 10.1016/j.compenvurbsys.2018.08.006.

Elmes A., Rogan J., Williams C., Ratick S., Nowak, D., \& Martin, D. (2017). Effects of urban tree canopy loss on land surface temperature magnitude and timing. ISPRS Journal of Photogrammetry and Remote Sensing, 128, 338-353, DOI: 10.1016/j.isprs.pprs.2017.04.011.

Farrugia S., Hudson M.D. \& McCulloch L. (2013). An evaluation of flood control and urban cooling ecosystem services delivered by urban green infrastructure. International Journal of Biodiversity Science, Ecosystem Services and Management, 9(2), 136-145, DOl: 10.1080/21513732.2013.782342.

Ferranti E.J.S., MacKenzie A.R., Ashworth K. \& Hewitt C.N. (2019). First Steps in Air Quality for Built Environment Practitioners. Retrieved from http://epapers.bham.ac.uk/3069/.

Fineschi S. \& Loreto F. (2020). A Survey of Multiple Interactions Between Plants and the Urban Environment. Frontiers in Forests and Global Change, 3(March), 1-19, DOI: 10.3389/ffgc.2020.00030.

Frantzeskaki N. (2019). Seven lessons for planning nature-based solutions in cities. Environmental Science and Policy, 93, 101-111, DOI:

10.1016/j.envsci.2018.12.033

Godinho S., Guiomar N. \& Gil A. (2018). Estimating tree canopy cover percentage in a mediterranean silvopastoral systems using Sentinel-2A imagery and the stochastic gradient boosting algorithm. International Journal of Remote Sensing, 39(14), 4640-4662, DOI: 10.1080/01431161.2017.1399480.

Greene C.S., Robinson P.J. \& Millward A.A. (2018). Canopy of advantage: Who benefits most from city trees? Journal of Environmental Management, 208, 24-35, DOI: 10.1016/j.jenvman.2017.12.015.

Guo T., Morgenroth J. \& Conway T. (2018). Redeveloping the urban forest: The effect of redevelopment and property-scale variables on tree removal and retention. Urban Forestry and Urban Greening, 35(August), 192-201, DOI: 10.1016/j.ufug.2018.08.012.

Guo T., Morgenroth J., Conway T. \& Xu C. (2019). City-wide canopy cover decline due to residential property redevelopment in Christchurch, New Zealand. Science of the Total Environment, 681, 202-210, DOI: 10.1016/.jscitotenv.2019.05.122.

Hilbert D.R., Koeser A.K., Roman L.A., Hamilton K., Landry S.M., Hauer R.J. ... Perez H. (2019). Development practices and ordinances predict inter-city variation in Florida urban tree canopy coverage. Landscape and Urban Planning, 190 (December 2018), 103603, DOI: 10.1016/j.landurbplan.2019.103603.

Hostetler A.E., Rogan J., Martin D., Delauer V. \& Oneil-Dunne J. (2013). Characterizing tree canopy loss using multi-source gis data in central Massachusetts, USA. Remote Sensing Letters, 4(12), 1137-1146, DOI: 10.1080/2150704X.2013.852704.

Husna V.N., Fawzi N.I. \& Nur I.A. (2018). Measuring and mitigating urban heat Island in Yogyakarta City using remote sensing. International Journal of Scientific and Technology Research, 7(7), 57-60. 
Intasen M., Hauer R.J., Werner L.P. \& Larsen E. (2017). Urban forest assessment in Bangkok, Thailand. Journal of Sustainable Forestry, 36(2), 148-163, DOI: 10.1080/10549811.2016.1265455.

Lavy B.L. \& Hagelman R.R. (2017). Spatial and Temporal Patterns Associated with Permitted Tree Removal in Austin, Texas, $2002-2011$. Professional Geographer, 69(4), 539-552, DOI: 10.1080/00330124.2016.1266953.

Lavy B.L. \& Hagelman R.R. (2019). Protecting the urban forest: Variations in standards and sustainability dimensions of municipal tree preservation ordinances. Urban Forestry \& Urban Greening, 44 (May), 126394, DOI: 10.1016/j.ufug.2019.126394.

Li X., Zhang C., Li W., Ricard R., Meng Q. \& Zhang W. (2015). Assessing street-level urban greenery using Google Street View and a modified green view index. Urban Forestry and Urban Greening, 14(3), 675-685, DOI: 10.1016/j.ufug.2015.06.006.

Liu L. \& Jensen M.B. (2018). Green infrastructure for sustainable urban water management: Practices of five forerunner cities. Cities, 74 (November 2017), 126-133, DOl: 10.1016/j.cities.2017.11.013.

Martin N.A., Chappelka A.H., Loewenstein E.F. \& Keever G.J. (2012). Comparison of carbon storage, carbon sequestration, and air pollution removal by protected and maintained urban forests in Alabama, USA. International Journal of Biodiversity Science, Ecosystem Services and Management, 8(3), 265-272, DOI: 10.1080/21513732.2012.712550.

McGee J.A., Day S.D., Wynne R.H. \& White M.B. (2012). Using Geospatial Tools to Assess the Urban Tree Canopy: Decision Support for Local Governments. Journal of Forestry, 110(5), 275-286, DOI: 10.5849/jof.11-052.

McGovern M. \& Pasher J. (2016). Canadian urban tree canopy cover and carbon sequestration status and change 1990-2012. Urban Forestry and Urban Greening, 20, 227-232, DOl: 10.1016/j.ufug.2016.09.002.

Morgenroth J., O'Neil-Dunne J. \& Apiolaza L.A. (2017). Redevelopment and the urban forest: A study of tree removal and retention during demolition activities. Applied Geography, 82, 1-10, DOI: 10.1016/j.apgeog.2017.02.011.

Norton B.A., Coutts A.M., Livesley S.J., Harris R.J., Hunter A.M. \& Williams N.S.G. (2015). Planning for cooler cities: A framework to prioritise green infrastructure to mitigate high temperatures in urban landscapes. Landscape and Urban Planning, 134, 127-138, DOI: 10.1016/j. landurbplan.2014.10.018

Nowak D.J. \& Greenfield E.J. (2018). Declining urban and community tree cover in the United States. Urban Forestry and Urban Greening, 32(November 2017), 32-55, DOI: 10.1016/j.ufug.2018.03.006.

Nowak D.J., Greenfield E.J., Hoehn R.E. \& Lapoint E. (2013). Carbon storage and sequestration by trees in urban and community areas of the United States. Environmental Pollution, 178, 229-236, DOI: 10.1016/j.envpol.2013.03.019.

Ossola A. \& Hopton M.E. (2018). Measuring urban tree loss dynamics across residential landscapes. Science of the Total Environment, 612, 940-949, DOI: 10.1016/j.scitotenv.2017.08.103.

Papastavrou V. (2019). Community engagement in urban tree management decisions: the Bristol case study. Arboricultural Journal, 41(2), 91-104, DOI: 10.1080/03071375.2019.1589173.

Pappalardo V., La Rosa D., Campisano A. \& La Greca P. (2017). The potential of green infrastructure application in urban runoff control for land use planning: A preliminary evaluation from a southern Italy case study. Ecosystem Services, 26(June 2016), 345-354, DOI: 10.1016/j. ecoser.2017.04.015.

Parmehr E.G., Amati M., Taylor E.J. \& Livesley S.J. (2016). Estimation of urban tree canopy cover using random point sampling and remote sensing methods. Urban Forestry and Urban Greening, 20, 160-171, DOl: 10.1016/j.ufug.2016.08.011.

Petri A.C., Wilson B. \& Koeser A. (2019). Planning the urban forest: Adding microclimate simulation to the planner's toolkit. Land Use Policy, 88 (August), 104117, DOI: 10.1016/j.landusepol.2019.104117.

Phelan K., Hurley J. \& Bush J. (2019). Land-Use Planning's Role in Urban Forest Strategies: Recent Local Government Approaches in Australia. Urban Policy and Research, 37(2), 215-226, DOI: 10.1080/08111146.2018.1518813.

Ramdhoni S., Rushayati S.B. \& Prasetyo L.B. (2016). Open Green Space Development Priority Based on Distribution of air Temperature Change in Capital City of Indonesia, Jakarta. Procedia Environmental Sciences, 33, 204-213, DOI: 10.1016/j.proenv.2016.03.071.

Riley C.B. \& Gardiner M.M. (2020). Examining the distributional equity of urban tree canopy cover and ecosystem services across United States cities. PLoS ONE, 15(2), 1-22, DOI: 10.1371/journal.pone.0228499.

Russo A., Escobedo F.J., Timilsina N., Schmitt A.O., Varela S. \& Zerbe S. (2014). Assessing urban tree carbon storage and sequestration in Bolzano, Italy. International Journal of Biodiversity Science, Ecosystem Services and Management, 10(1), 54-70, DOI: 10.1080/21513732.2013.873822.

Saptutyningsih E. \& Ma'ruf A. (2015). Measuring the Impact of Urban Air Pollution: Hedonic Price Analysis and Health Production Function. Jurnal Ekonomi Pembangunan: Kajian Masalah Ekonomi Dan Pembangunan, 16(2), 146, DOl: 10.23917/jep.v16i2.1459.

Seiferling I., Naik N., Ratti C., \& Proulx R. (2017). Green streets - Quantifying and mapping urban trees with street-level imagery and computer vision. Landscape and Urban Planning Journal, 93-101.

Singapore National Parks Board (2020). Urban Biodiversity. Available online: https://www.nparks.gov.sg/biodiversity/urban-biodiversity (Accessed on 25 August 2020).

Soga M. \& Gaston K.J. (2020). The ecology of human - nature interactions. In roc. R. Soc. B 287: 20191882, DOI: 10.1098/rspb.2019.1882.

Tang Y., Chen A. \& Zhao S. (2016). Carbon storage and sequestration of urban street trees in Beijing, China. Frontiers in Ecology and

Evolution, 4 (May), 1-8, DOl: 10.3389/fevo.2016.00053.

Trees \& Design Action Group (2012). Trees in the Townscape: A Guide for Decision Makers, 3. Available online: www.tdag.org.uk.

Trees \& Design Action Group (2014). Trees in Hard Landscapes A Guide for Delivery, 1-162. Retrieved from www.tdag.org.uk/trees-inhard-landscapes.

Turner-Skoff J.B. \& Cavender N. (2019). The benefits of trees for livable and sustainable communities. Plants, People, Planet, 1(4), 323-335,

DOl: 10.1002/ppp3.39.

Ulmer J.M., Wolf K.L., Backman D.R., Tretheway R.L., Blain C.J., O'Neil-Dunne J.P. \& Frank L.D. (2016). Multiple health benefits of urban tree canopy: The mounting evidence for a green prescription. Health and Place, 42, 54-62, DOI: 10.1016/j.healthplace.2016.08.011.

UN HABITAT (2016). MEASUREMENT OF CITY PROSPERITY: Methodology and Metadata.

United Nations (2019). Trees in Cities Challenge. Retrieved from https://sustainabledevelopment.un.org/partnership/?p=32508.

van der Jagt A. P. N. \& Lawrence A. (2019). Local government and urban forest governance: insights from Scotland. Scandinavian Journal of Forest Research, 34(1), 53-66, DOI: 10.1080/02827581.2018.1532018.

Zhou W., Wang J. \& Cadenasso M.L. (2017). Effects of the spatial configuration of trees on urban heat mitigation: A comparative study. Remote Sensing of Environment, 195, 1-12, DOI: 10.1016/j.rse.2017.03.043. 